\title{
Construction Project Control in the UK: Current Practice, Existing Problems and Recommendations for Future Improvement
}

\author{
Yakubu Olawale, PhD, MBA, MRICS ${ }^{a}$ and Ming Sun, PhD (Professor) ${ }^{b}$ \\ ${ }^{a}$ Engineering Systems and Management, School of Engineering and Applied Science, Aston University, Birmingham, B4 7ET, UK. \\ ${ }^{\mathrm{b}}$ School of the Built Environment, Heriot-Watt University, Edinburgh, EH14 4AS, UK. \\ Published in International Journal of Project Management 33(3) 623-637
}

\begin{abstract}
The aim of this study is to address the main deficiencies with the prevailing project cost and time control practice for construction projects in the UK. A questionnaire survey was carried out with 250 top companies to establish the current practice and identify existing problems. This was followed by in-depth interviews with 15 experienced practitioners from these companies in order to gain further insights of the identified problems, and their experience of good practice on how these problems can be tackled. On the basis of these interviews and synthesis with existing literature, a list of 65 good practice recommendations have been developed for the key project controls tasks: planning, monitoring, reporting and analysing. The Delphi method was then used, with the participation of a panel of 8 practitioner experts, to evaluate these improvement recommendations and to establish the degree of their relevance. After two rounds of the Delphi, these recommendations are put forward as "critical", "important", or "helpful" measures for improving project control practice in the UK construction industry.
\end{abstract}

Keywords: Project control, cost control, project overrun, project management practice, project success, good practice.

Cite as: Olawale, Y. and Sun, M. (2015). Construction project control in the UK: current practice, existing problems and recommendations for future improvement. International journal of project management, 33(3), 623-637. 


\section{Introduction}

Project based practice is common for many organisations in different industrial sectors, from an oil company developing an exploration site, to an investment bank installing a new IT system; from a technology company developing and launching a new type of mobile phone to a marketing consulting company helping a retailer with the launch of a new marketing campaign. One of the distinguishing features is that projects are normally required to complete within specified timeframe and an allocated cost budget. On the other hand, there are many uncertain factors that have potential impact on time and cost during project delivery. In the construction industry, which mainly deals with one-off projects, the influence of uncertainties is more prevalent, necessitating the need for effective management control. According to Baguley (2008), controlling is part of management and can generally be defined as an implicit part of managing. In a project context, control is one of the major tools of project management; this is clearly indicated in most widely accepted definitions of project management such as those by the Association for Project Management (APM, 2006) and Project Management Institute (PMI, 2008). "Project control can be defined as the application of processes to measure project performance against the project plan, to enable variances, to be identified and corrected, so that project objectives are achieved" (APM 2010).

In terms of construction projects, time and cost are two of the essential areas that stand out when it comes to control (Cooke and Williams, 2004). Ruskin and Estes (1995), highlighted that project cost control is about assuring that work elements within a project are accomplished within their respective budget. Hence, in construction projects, which normally involve a significant amount of cost investment; it is absolutely important to control cost in the interest of both the contractor and the client. The control of time on the other hand is also

Cite as: Olawale, Y. and Sun, M. (2015). Construction project control in the UK: current practice, existing problems and recommendations for future improvement. International journal of project management, 33(3), 623-637. 
often referred to as schedule control. According to Heldman (2005), it involves determining the status of the project schedule, determining if changes have occurred or should have, and influencing and managing schedule changes. Chang (2002) found that the reasons for cost increases are normally also the reasons for time extensions. Hence this study is devoted to studying cost and time control together in the argument that it is difficult to separate these two concepts. Despite the existence of numerous studies in this broad area, there has been a dearth of studies specific to improving the construction project control process in practice. Studies like Cornick and Osbon (1994), Egbu et al (1998) and Akintoye and Fitzgerald (2000) did not focus on the construction project control practice in totality but only on part of the process such as techniques and estimating. Paradoxically, industry reports have either implicitly or explicitly acknowledged the need for a study in this area. For example, the Egan report (1998) highlighted the need to examine current practice in the construction industry and the scope for improving it, while the 'Managing the Risk of Delayed Completion in the $21^{\text {st }}$ Century' report (CIOB 2008) explicitly stated that "while it is apparent that some projects are managed very well in the UK, it has to be recognised that the quality of timemanagement on construction projects is generally poor" with room for improvement. These sorts of clamours and coupled with a lack of recent research on the overarching practice of project cost and time control in the UK construction industry has necessitated the need for a study from this particular perspective. On this basis, this study sets: (1) to explore how cost and time of building construction projects are controlled by professionals in practice in the UK in order to unearth the prevalent processes and the deficiencies surrounding project control in practice; and (2) to use the findings of the study to recommend how the project control process can be improved.

Cite as: Olawale, Y. and Sun, M. (2015). Construction project control in the UK: current practice, existing problems and recommendations for future improvement. International journal of project management, 33(3), 623-637. 


\section{Literature Review}

A thorough literature review has revealed that existing studies on project control can be broadly divided into three categories: (1) those on the negative consequence of ineffective project control, such as delay and cost overrun; (2) those on development of project control techniques and models that can improve the cost and time performance of projects; (3) a small number of studies on project controls in practice. Each of these is discussed in the following sections.

\section{Project Delay and Cost Overrun}

It is understandable that more studies concentrated on delays and cost overruns because these problems have been widely acknowledged the world over. In the UK for example, a survey carried out by the Chartered Institute of Building (CIOB) revealed that on the whole complex construction projects in the UK are likely to be finished more than six months late (CIOB, 2008). A year earlier Hoffman et al (2007) investigated 332 facility projects funded by the US Air Force and found that $72 \%$ were not completed within the specified benchmark (time) goals. Odeck (2004) investigated the statistical relationship between actual and estimated costs of road construction in Norway and found the mean cost overrun as $7.88 \%$ noting that cost overrun is more predominant in projects than cost savings. Kumaraswamy and Chan (1998) found a mean percentage time overrun of $9 \%$ and $17 \%$ for government and private building projects respectively in Hong Kong. Aibinu and Jagboro (2002), through a questionnaire survey in Nigeria, revealed that average time overrun of building projects could range from $59.23 \%$ to $92.64 \%$ depending on the value of the project. Shehu et al (2014) carried out a survey of 359 completed projects in Malaysia and found that $55 \%$ experienced cost overruns. Flyvbjerg et al (2003) also found that $90 \%$ of infrastructure projects experience

Cite as: Olawale, Y. and Sun, M. (2015). Construction project control in the UK: current practice, existing problems and recommendations for future improvement. International journal of project management, 33(3), 623-637. 
cost escalation. It was noted that cost overrun of infrastructure projects appears to be a global phenomenon, with the research showing cost escalation of projects existing in the 20 countries (across five continents) studied.

In addition to the magnitude of cost and time overrun, many studies also embarked on identifying the causes of delays and cost overruns revealing a variety but often similar issues. For example, issues to do with design changes and poor change control have been identified as a major cause of cost and time overrun (Kumaraswamy and Chan, 1998; Kaming et al, 1997; Kaliba et al, 2009; Koushki et al, 2005; Assaf and Al-Hejji, 2006; Al-Momani, 2000; Hsieh et al, 2004). Sun and Meng (2009) proposed a taxonomy on the basis of synthesis of existing studies, which provides a comprehensive overview of possible causes of project change. Allied to design changes is the issue of clarity of scope which was found by Cheng (2014) as the leading influencing factor of cost overrun of construction projects. Financing and payment issues also seem to be a common theme identified as possible cause of delay and cost overrun (Abdul-Rahman et al 2006; Frimpong et al, 2003; Kaliba et al, 2009; Mansfield et al, 1994; Assaf et al, 1995). Inaccurate estimates of cost and/or duration is also one of the most frequently identified causes of project overrun (Jennings 2012, Mansfield et al, 1994, Lee 2008, Shane et al 2009). Finally, the issue of planning optimism and deficiency has also been widely reported as one of the factors causing delay and cost overrun (Kaming et al, 1997; Chang, 2002; Hseih et al, 2004; Assaf and Al-hejji 2006).

\section{Project Control Models and Techniques}

The majority of the studies devoted to the development of project control models and techniques have mostly developed computer based project control systems incorporating quantitative project management concepts such as Earned Value Analysis (EVA) (Acebes et

Cite as: Olawale, Y. and Sun, M. (2015). Construction project control in the UK: current practice, existing problems and recommendations for future improvement. International journal of project management, 33(3), 623-637. 
al, 2014). A common motivation for these studies is the desire to make project control models more easy to use in practice, as stated by Jung and Kang (2007), Kaka (1999), Kim and Liu (2007), Benjaoran (2009) and Marco et al (2009). Another common motivation that has informed the development of project control models is the need for integration. For example, Alshawi and Hassan (1999), Gorog (2009) and Cho et al (2010) developed different models that integrated the schedule and cost information with resource information in order to achieve efficient planning of construction processes. These studies focused on the project planning process instead of on the control process during project execution. The need for monitoring and control actions arises because projects are dynamic in nature and are often carried out in changing environments. Such dynamic characteristics of projects were not sufficiently considered by the existing project control studies, as criticised by Barraza and Bueno (2007), Rozenes et al (2004), Fena-Mora and Li (2001), Falco and Macchiaroli (1998).

Finally, some studies have attempted to improve the much acclaimed earned value method for example; Khamooshi and Golafshani (2014) noted that the EVA uses cost as a proxy to measure schedule performance in order to control the duration of a project and that this may not be effective. The study developed a new method called the Earned Duration Management (EDM) which generates a number of indexes which are better measure of schedule performance during project control. Naeni et al (2011) on the other hand suggested incorporating the fuzzy principles into earned value calculations as a means of assisting project managers to estimate the future status of the project in a more robust and a more reliable way. Similarly, Aliverdi et al (2014) proposed the use of statistical quality control charts in EVA in order to improve its capability of reporting deviation, hence contributing to

Cite as: Olawale, Y. and Sun, M. (2015). Construction project control in the UK: current practice, existing problems and recommendations for future improvement. International journal of project management, 33(3), 623-637. 
a more reliable project control process. On the issue of better assessment of deviations, Acebes et al (2014) integrated the earned value methodology with project risk analysis in the argument that this approach will help project managers better understand the origin of project deviations and, therefore be able to take early corrective actions during project control.

\section{Project Control Practice}

There have been very few studies on practices for improving the specific activity of project control in practice. One of such studies is Mckim and Hegazy (2000), who identified that cost control planning using the cost breakdown structure and a budget baseline yields better results than controlling using work packages alone and that the use of detailed bar charts and CPM analysis techniques correlated with good schedule performance. More recently, Haponava and Al-jibouri (2010) argued that project control practice has traditionally focused on product-based goals and argued for the need to shift the emphasis towards processoriented goals.

Studies on project control practice specific to the UK are even rarer with most studies in the area concentrating on just an aspect of the project control process. Egbu et al (1998) explicitly focused only on project control techniques and not the overarching process. It is however worthy of note that some conclusions in relation to project control may have wider applications. For example, it was found that planners' contribution ceases to have any significant impact on the planning process once construction starts. Cornick and Osbon (1994) revealed that the systems and procedures used by the company's quantity surveyors differed from site to site and that the cost information they produced was not presented in formats that other company disciplines could readily use. Akintoye and Fitzgerald (2000) on the other hand focused on estimating which is usually the starting point of project control.

Cite as: Olawale, Y. and Sun, M. (2015). Construction project control in the UK: current practice, existing problems and recommendations for future improvement. International journal of project management, 33(3), 623-637. 
Revealing that cost estimating within firms in the UK is used predominantly to prepare tenders for clients, monitor project execution and audit project success.

\section{Research Methodology}

This study adopted a mixed research methodology, consisting of both quantitative and qualitative research methods, including:

- Questionnaire survey: The main aim was to find out the current practice of project cost and time control. The survey was targeted at large construction companies, since they are more likely to adopt formal project control practices. A total of 250 questionnaires were administered; 150 to the top construction companies in the UK by company turnover and the remaining 100 to the top construction project consultancies in the country by the number of professional staff employed and company fee earnings.

- Interviews: It was adopted in a bid to provide further insight into some of the issues that emanated from the analysis of the preceding questionnaire survey. Interviewees were sampled from the 250 companies who participated during the questionnaire survey. A total of 15 practitioners were interviewed; the majority of them were directors and senior managers with vast experience in building construction project management. All interviews were conducted in a semi-structured format. Interviewees were asked the same questions by the researcher following a pre-defined guide. All interviews were recorded and transcribed afterwards for analysis.

- Delphi method: Following the analysis the interviews, together with synthesis of literature, a list of recommendations was produced for the improvement of project control in practice. Delphi method was used with the involvement of 8 building practice, existing problems and recommendations for future improvement. International journal of project management, 33(3), 623-637. 
construction practitioner experts in order to establish the degree of relevance of these recommendations.

\section{Survey Findings: Current Practice of Project Control}

The questionnaires were distributed to the top 150 construction companies in the UK by turnover and the top 100 construction consultancies in the UK by fee earned and number of professional staff employed. This information was obtained from the annual league table published by the Building magazine. Due to the fact that the league table only gives the names of the companies but not their addresses, an internet search was conducted to find the addresses where the questionnaires would be sent. Telephone calls were subsequently made to these companies to confirm the addresses and to find out the type of hierarchy and structure that exists within the organisation. This enabled the questionnaires to be sent to the appropriate department. To augment this, the name of a construction director, manager or the appropriate personnel with a huge responsible for the management of construction projects in the organisation was obtained in order to ensure that the questionnaires went to the correct addresses and addressed to the appropriate personnel. This ensured a very good response rate; as a total of 68 questionnaires were returned by contractors ( $45 \%$ response rate) and 42 were returned by consultants ( $42 \%$ response rate). These are quite good for a survey of this type as evident from similar surveys such as Akintoye and Fitzegerald (2000), Kumaaswamy and Chan (1998), and Iyer and Jha (2005) with response rates of $42 \%, 37 \%$, and $25 \%$ respectively. Nearly $72 \%$ of the respondents that completed the questionnaires were directors or senior managers in the area of construction commercial and project management with $48 \%$ of respondents possessing more than 25 years of experience in the construction industry.

Cite as: Olawale, Y. and Sun, M. (2015). Construction project control in the UK: current practice, existing problems and recommendations for future improvement. International journal of project management, 33(3), 623-637. 
Questions included in this survey were broader than the focus of this paper. Details of the survey itself and analysis of other aspects have been reported in earlier publications for example; see Olawale and Sun (2010). In the following, only analysis of the current project control practice is presented.

\section{How Time and Cost of Construction Projects are Estimated}

Cost and time of construction projects are controlled with the objective of delivery within a predetermined time and a cost budget. Determining these objectives is the starting point of project control because it serves as a baseline to measure against. As part of the survey, it was deemed necessary to know how contractors and consultants determine the time and cost estimate of their construction projects. Respondents were asked to indicate the method(s) used in determining the duration and cost of their construction projects. Table 1 shows the results when respondents were asked how the time duration of their projects are determined which shows that more than half of the responding consultants $(53.8 \%)$ determine the duration of their construction activities by experience based methods only while just $16.7 \%$ of contractor base the method of determining their construction projects on experience only. It can also be seen that $35.7 \%$ of contractors determine the duration of their construction projects by techniques based on calculations while just $11.5 \%$ of responding consultants indicated this technique. From the table $35.7 \%$ of responding contractors indicated that they determine the duration of their projects by a combination of experience and calculations while $23.1 \%$ of responding consultants use this technique. A test of statistical significance was conducted, using Z-test (Kirk, 1999), on the responses of the contractors and consultants. The Z-test showed a significant difference between the two groups with regards the questions about use of "experience only" and use of "calculations only" in determining the time/duration of their construction projects. Consultants tend to rely more on experience;

Cite as: Olawale, Y. and Sun, M. (2015). Construction project control in the UK: current practice, existing problems and recommendations for future improvement. International journal of project management, 33(3), 623-637. 
while contractors in comparison rely more on techniques based on calculation. There is no significant difference between the two groups for the other three answers. A sizable proportion of contractors (35.7\%) and consultants (23.1\%) use a combination of calculations and experience; a small proportion of both groups used other techniques or no specific method at all.

Table 1: How duration of construction activities/projects are determined

\begin{tabular}{lll}
\hline & Contractors & Consultants \\
\hline By experience only & $16.7 \%$ & $53.8 \%$ \\
Techniques based on calculations only & $35.7 \%$ & $11.5 \%$ \\
Combination of calculations and experience & $35.7 \%$ & $23.1 \%$ \\
Other techniques apart from the above & $4.8 \%$ & $7.7 \%$ \\
Do not use any techniques & $7.1 \%$ & $3.8 \%$ \\
\hline
\end{tabular}

Table 2 shows the result obtained when respondents were asked about how the cost of their projects was determined. Compared with methods for deciding project duration, more people from both groups rely on calculations alone or a combination of calculations and experience. Very few contractors use experience only or other techniques in determining project costs. In contrast, $19.2 \%$ of consultants claimed that they rely on experience alone for this task. The Ztest of significance showed no significance difference in the responses to the questions in this category apart from responses to the use of experience only.

Table 2: How cost of construction projects are estimated

\begin{tabular}{lll}
\hline & Contractors & Consultants \\
\hline By experience only & $2.0 \%$ & $19.2 \%$ \\
Techniques based on calculations only & $59.0 \%$ & $46.2 \%$ \\
Techniques based on combination of & $29.0 \%$ & $27.0 \%$ \\
calculations and experience & & \\
Other techniques apart from the above & $5.0 \%$ & $8.0 \%$ \\
\hline
\end{tabular}

\section{Project Cost and Time Control Techniques}

A literature review was initially done to find out the cost and time control techniques available for use on construction projects. This was presented to the respondents who were asked to choose the technique(s) they commonly use. The result obtained from analysis of the practice, existing problems and recommendations for future improvement. International journal of project management, 33(3), 623-637. 
questionnaire is shown in Tables 3 and 5. For time control techniques, there is a strong similarity between both groups. $35 \%$ of responding contractors indicated that they utilise Gantt Bar Chart and 33\% of responding consultants utilise the same technique. $28 \%$ of contractors indicated that they use CPM and $34 \%$ of consultants use the method. This trend reflects even in the less commonly use methods as can be seen from the table.

Table 3: Techniques used for project planning and time control

\begin{tabular}{lll}
\hline Techniques & Contractors & Consultants \\
\hline Gantt Bar Chart & $35.0 \%$ & $33.0 \%$ \\
Critical Path Networks/Method (CPM) & $28.0 \%$ & $34.0 \%$ \\
Milestone Date Programming Technique & $17.0 \%$ & $17.0 \%$ \\
Program Evaluation and Review Technique (PERT) & $10.0 \%$ & $9.0 \%$ \\
Precedence Network Diagram (PND) & $2.0 \%$ & $2.0 \%$ \\
Elemental Trend Analysis/Line of Balance (LOB) & $5.0 \%$ & $2.0 \%$ \\
Other techniques apart from the above & $5.0 \%$ & $8.0 \%$ \\
\hline
\end{tabular}

The survey also revealed the use of various software packages for the purpose of project planning and time control (Table 4). The top three packages were Microsoft Project, Asta Power Projects and Primavera. Their combined usage accounts for over $90 \%$ for both contractors and consultants.

Table 4: Software packages used for project planning/time control

\begin{tabular}{lll}
\hline Planning/Scheduling/Time control software & Contractors & Consultants \\
\hline Microsoft Project & $35 \%$ & $57 \%$ \\
Asta Powerproject & $44 \%$ & $19 \%$ \\
Primavera & $15 \%$ & $19 \%$ \\
Project Commander & $4 \%$ & $5 \%$ \\
Deltek Open Plan & $2 \%$ & - \\
\hline
\end{tabular}

The Z-test did not show any significant difference between the responses of the contractors and consultants for cost control techniques either (Table 5). $22 \%$ of responding contractors utilise project cost value reconciliation so does $20 \%$ of consultants. $7 \%$ of contractors indicated they use earned value analysis as compared to $11 \%$ of consultants, $18 \%$ of 
contractors utilise actual vs. forecasted method and $11 \%$ of consultants use this technique.

PERT/Cost was utilised by $7 \%$ of contractors and by $4 \%$ of consultants.

Table 5: Techniques used for project cost control

\begin{tabular}{lll}
\hline Techniques & Contractors & Consultants \\
\hline Project Cost-Value Reconciliation & $22.0 \%$ & $20.0 \%$ \\
Overall profit or Loss & $15.0 \%$ & $16.0 \%$ \\
Labour/Plant/Material (actual versus forecast reconciliation) & $18.0 \%$ & $11.0 \%$ \\
Profit or loss on each contract at valuation dates & $17.0 \%$ & $10.0 \%$ \\
Unit Costing & $8.0 \%$ & $13.0 \%$ \\
Standard Costing & $6.0 \%$ & $14.0 \%$ \\
Earned Value Analysis & $7.0 \%$ & $11.0 \%$ \\
Program Evaluation and Review Technique (PERT/COST) & $7.0 \%$ & $4.0 \%$ \\
Leading Parameter Method & - & $1.0 \%$ \\
\hline
\end{tabular}

A variety of software packages were utilised for cost control by respondents (Table 6). The table shows that bespoke/in-house software packages was utilised by the highest proportion in both groups as $29 \%$ of contractors and $38 \%$ of consultants. Popular 'off the shelf' commercial packages include Microsoft Project, Project Costing System (PCS), Asta Powerproject, and Primavera Suretrack. Three out of these four, with the exception of PCS, were also found to be used for time control purpose. Small proportion of both groups used the general purpose Excel spreadsheet and specialist cost control packages, such as COINS and WinQS.

Table 6: Software packages used for project cost control

\begin{tabular}{lll}
\hline Cost control software & Contractors & Consultants \\
\hline Bespoke/in-house packages & $29.00 \%$ & $38.00 \%$ \\
Microsoft Project & $20.00 \%$ & $32.00 \%$ \\
Project Costing System (PCS) & $15.00 \%$ & $11.00 \%$ \\
Asta Powerproject & $15.00 \%$ & $5.00 \%$ \\
Primavera Suretrak & $8.00 \%$ & $5.00 \%$ \\
Excel Spreadsheet & $7.00 \%$ & $3.00 \%$ \\
Construction industry software (COINS) & $5.00 \%$ & $3.00 \%$ \\
WinQS & - & $3.00 \%$ \\
\hline
\end{tabular}

\section{Frequency of Application of Project Controls}

The survey also sought to discover how frequently project cost and time control is applied to construction projects in the UK (Table 7). Both contractors and consultants vastly apply Cite as: Olawale, Y. and Sun, M. (2015). Construction project control in the UK: current practice, existing problems and recommendations for future improvement. International journal of project management, 33(3), 623-637. 
control methods on their projects. $93 \%$ of contractors either frequently or always apply their time control method as compared to $80 \%$ of responding consultants. When it comes to cost control $100 \%$ of contractors either frequently or always utilise their cost control method and an equal proportion, $100 \%$ of consultants apply cost control on their projects. The application of cost control is more overwhelming than the application of time control and confirms the suggestions of other researchers like Sohail et al (2002) that construction professionals seem to pay more attention to cost performance of projects than time performance. The frequency of application of project cost and time control is buttressed from the interviews where nearly all interviewees confirmed that they embark on project controls.

Table 7: Frequency of application of cost and time control by contractors and consultants

\begin{tabular}{lllll}
\hline Frequency of usage & \multicolumn{2}{c}{ Contractors } & \multicolumn{2}{c}{ Consultants } \\
\hline & Time Control & Cost Control & Time Control & Cost Control \\
\hline Always & $76.0 \%$ & $93.0 \%$ & $30.8 \%$ & $69.2 \%$ \\
Frequently & $17.0 \%$ & $7.0 \%$ & $50.0 \%$ & $30.8 \%$ \\
Rarely/Not at all & $7.0 \%$ & - & $19.2 \%$ & - \\
\hline
\end{tabular}

\section{Interview Analysis: Existing Problems of Project Control Practice}

The interview questions were derived from literature review and the outcome of the earlier questionnaire survey described above. A total of 28 questions were included, under the following themes: (1) general knowledge of project control and the techniques used in the interviewees' companies; (2) description of the process of project control in the company; (3) problems and catalyst to the project control process in the organisation; (4) strengths and weaknesses of the project control process; and; (5) how the project control process could be improved.

Cite as: Olawale, Y. and Sun, M. (2015). Construction project control in the UK: current practice, existing problems and recommendations for future improvement. International journal of project management, 33(3), 623-637. 
The top construction companies and construction project consultancies in the UK were approached for interviews. A total of 15 companies presented relevant practitioners for interviews. The details of the interviewees are shown in Table 8 where it can be seen that majority of the interviewees are directors and senior managers with vast experience in construction project management. It was decided that interviewees of this pedigree are well placed to provide a more holistic account of the project control practice in their organisations. The total professional experience of the 15 interviewees is 422 years. The same questions were asked in all interviews for objectivity and ease of analysis. The questions were open ended in order to allow practitioners to fully express themselves albeit in a structured way. The total duration of the interviews conducted is 510 minutes with an average duration of 34 minutes spent on each interview. The data obtained from the interviews were analysed manually (aided by a computer spreadsheet) but systematically as explained by Ritchie et al (2003).

Cite as: Olawale, Y. and Sun, M. (2015). Construction project control in the UK: current practice, existing problems and recommendations for future improvement. International journal of project management, 33(3), 623-637. 
Table 8 Profiles of interviewees

\begin{tabular}{|c|c|c|c|c|c|}
\hline & Roles & Years* & $\begin{array}{l}\text { Company } \\
\text { type }\end{array}$ & Project types & $\begin{array}{l}\text { Interview } \\
\text { duration }\end{array}$ \\
\hline 1 & $\begin{array}{l}\text { Senior general } \\
\text { project manager }\end{array}$ & 30 & $\begin{array}{l}\text { Main } \\
\text { contractor }\end{array}$ & Construction, civil engineering, nuclear etc. & $50 \mathrm{~min}$ \\
\hline 2 & $\begin{array}{l}\text { Commercial } \\
\text { director }\end{array}$ & 25 & $\begin{array}{l}\text { Main } \\
\text { contractor }\end{array}$ & $\begin{array}{l}\text { Building construction, telecommunication, } \\
\text { infrastructure, civil engineering }\end{array}$ & $40 \mathrm{~min}$ \\
\hline 3 & Director & 25 & Contractor & Building and engineering services & $30 \mathrm{~min}$ \\
\hline 4 & Associate director & 28 & Consultant & Construction & $30 \mathrm{~min}$ \\
\hline 5 & $\begin{array}{l}\text { Senior contracts } \\
\text { manager }\end{array}$ & 24 & $\begin{array}{l}\text { Main } \\
\text { contractor }\end{array}$ & Social housing/regeneration & $40 \mathrm{~min}$ \\
\hline 6 & Planning director & 28 & $\begin{array}{l}\text { Main } \\
\text { contractor }\end{array}$ & $\begin{array}{l}\text { Building, Transport infrastructure, Civil } \\
\text { engineering }\end{array}$ & $50 \mathrm{~min}$ \\
\hline 7 & Director & 45 & Consultant & Construction & $35 \mathrm{~min}$ \\
\hline 8 & Head of planning & 20 & $\begin{array}{l}\text { Main } \\
\text { contractor }\end{array}$ & Building construction & $15 \min$ \\
\hline 9 & Regional manager & 34 & $\begin{array}{l}\text { Main } \\
\text { contractor }\end{array}$ & Building, construction and civil engineering & $20 \mathrm{~min}$ \\
\hline 10 & Director & 25 & $\begin{array}{l}\text { Main } \\
\text { contractor }\end{array}$ & Building construction & $30 \mathrm{~min}$ \\
\hline 11 & $\begin{array}{l}\text { Senior programme } \\
\text { manager }\end{array}$ & 11 & Consortium & Infrastructure, construction & $45 \mathrm{~min}$ \\
\hline 12 & Director & 40 & $\begin{array}{l}\text { Main } \\
\text { contractor }\end{array}$ & Building construction and civil engineering & $35 \mathrm{~min}$ \\
\hline 13 & $\begin{array}{l}\text { Head of project } \\
\text { planning }\end{array}$ & 20 & $\begin{array}{l}\text { Main } \\
\text { contractor }\end{array}$ & Building and construction & $30 \mathrm{~min}$ \\
\hline 14 & Director & 22 & $\begin{array}{l}\text { Consultants } \\
\text { and } \\
\text { contractor }\end{array}$ & $\begin{array}{l}\text { Construction, infrastructure and } \\
\text { engineering }\end{array}$ & $30 \mathrm{~min}$ \\
\hline 15 & Director & 25 & $\begin{array}{l}\text { Main } \\
\text { contractor }\end{array}$ & Construction & $30 \mathrm{~min}$ \\
\hline
\end{tabular}

* Number of years of experience in the construction industry

The major steps taken in analysing the data from the interviews is depicted in Figure 1 . The first step of qualitative analysis involved transcribing the interview recordings using the interview guide as a structure. The familiarisation process entailed listening to the recorded interviews over and over again and repeated reading of the transcripts. During the familiarization process, emerging themes and any potential concept were noted and listed.

Cite as: Olawale, Y. and Sun, M. (2015). Construction project control in the UK: current practice, existing problems and recommendations for future improvement. International journal of project management, 33(3), 623-637. 
These were assigned to columns in an excel spreadsheet and the emerging concepts were assigned to the rows of the new themes.

The next step was to try and find links between the themes and concepts and produce an index in order to provide a hierarchy and grouping of some sort. This process of data sorting allowed information with similar content or properties to be located together allowing focus on each subject in turn so that the detail and distinction that lie within could be unraveled. After the indexing of the concepts it was imperative to summarize the original data to a more manageable level but during this process the key terms and phrases of respondent were retained in the respondent own language as much as possible. Categorization and classification of the synthesized data was the next step in the analysis of the data. Categorization allowed for refinement and assignment of descriptive data to the synthesized information while classification was needed so that groups of categories can be packed together under a higher level. This was followed by detecting for pattern of association. This stage of the qualitative analysis was an iterative process that involved looking through data, recurring themes and searching for association. This involved reading across the charted data, moving and reading through two or sometimes three columns at the same time to see if any emergent patterns are replicated across the data set.

Cite as: Olawale, Y. and Sun, M. (2015). Construction project control in the UK: current practice, existing problems and recommendations for future improvement. International journal of project management, 33(3), 623-637. 


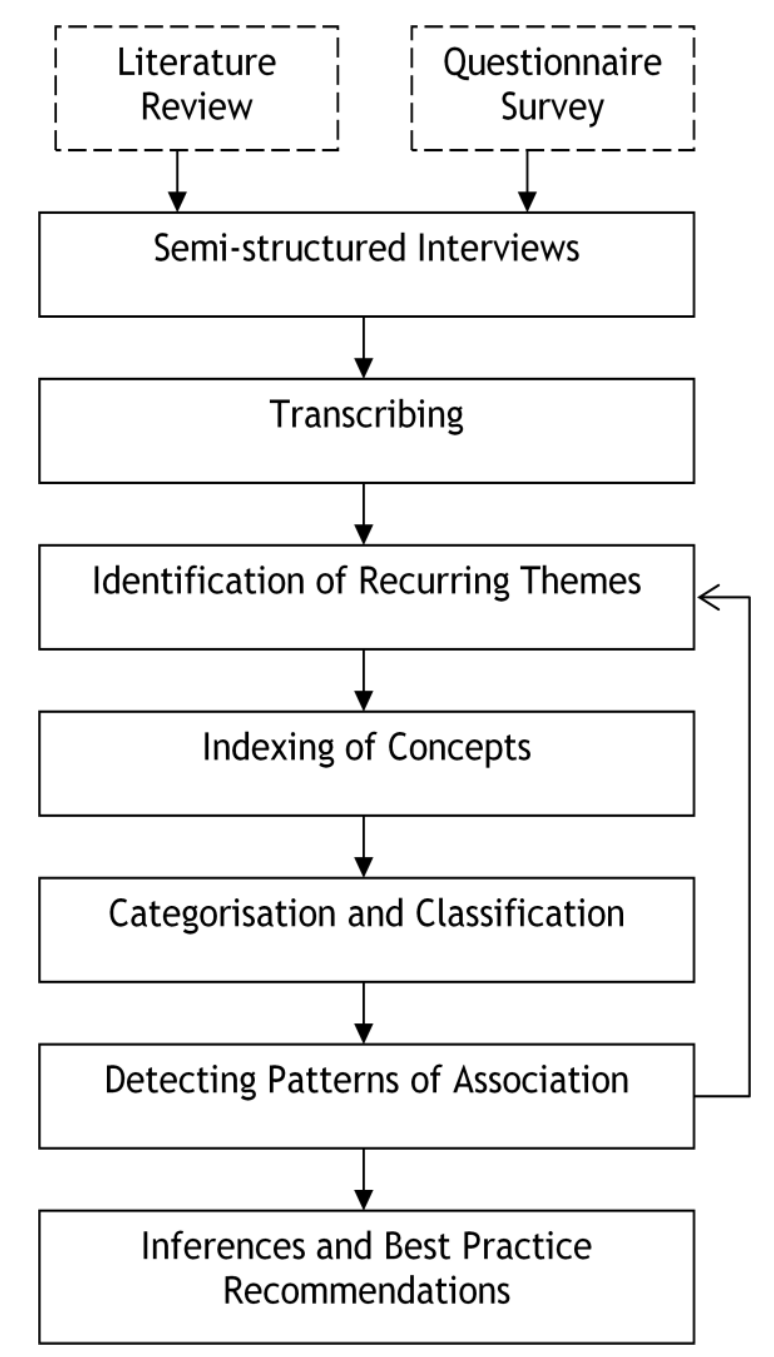

Figure 1 Interview analysis procedure

A key revelation of interview study is that project cost and time control is not often integrated in practice. In view of this, the prevalent project control process in practice is presented separately for time control and cost control as mostly found in practice. It was also found that project control usually involves several distinctive tasks (Olawale and Sun, 2013):

- Planning: This is the task to determine project objectives and activities needed to achieve these objectives. Time schedules are decided by sequencing the project practice, existing problems and recommendations for future improvement. International journal of project management, 33(3), 623-637. 
activities, with interim milestones. At the same time, detailed cost estimates and cost plans are also produced.

- Monitoring: Once the execution of project plans starts, project progress needs to be monitored to ensure that activities are carried out as planned and costs and spending occur for the correct amount and at the correct time. Any variations to time and cost plans need to be identified.

- Reporting: The information gathered during the monitoring step will need to be presented in some agreed format and transmitted via the appropriate medium to the appropriate department or personnel for further action e.g. analysis. The report is where the information collected during monitoring is contained and it is analysis of this information that shows the status of the project as described below.

- Analysing: Having gathered the data, the team must determine whether the project is behaving as predicted, and if not, calculate the size and impact of the variances.

Interview analysis also revealed a range of problems with the existing practice for each of the above tasks, as summarised in Table 9.

Cite as: Olawale, Y. and Sun, M. (2015). Construction project control in the UK: current practice, existing problems and recommendations for future improvement. International journal of project management, 33(3), 623-637. 
Table 9: Identified problems with the current project control practice

\begin{tabular}{|c|c|c|}
\hline Control task & Time Control & Cost Control \\
\hline Planning & 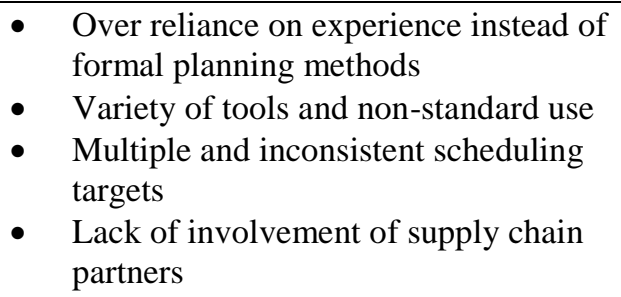 & $\begin{array}{l}\text { - No plan is made on how cost is } \\
\text { controlled } \\
\text { Rarely develop estimates from } \\
\text { basis but amalgamate quotations } \\
\text { from various work package } \\
\text { suppliers }\end{array}$ \\
\hline Monitoring & $\begin{array}{l}\text { - No dedicated monitoring regime on } \\
\text { site } \\
\text { - Monitoring usually not objective } \\
\text { yielding optimistic verdict } \\
\text { - No clear distinction between } \\
\text { monitoring and reporting appears to } \\
\text { exist with less emphasis on } \\
\text { monitoring }\end{array}$ & $\begin{array}{l}\text { - No clear distinction between } \\
\text { monitoring and reporting appears } \\
\text { to exist with less emphasis on } \\
\text { monitoring } \\
\text { - Monitoring regime quite often } \\
\text { does not follow a periodic regime } \\
\text { Monitoring usually does not } \\
\text { utilise a dedicated structure such } \\
\text { as computer systems or templates }\end{array}$ \\
\hline Reporting & $\begin{array}{l}\text { - No formal reporting mechanism } \\
\text { between site and office } \\
\text { - Non-factual reporting due to optimism } \\
\text { on project time status } \\
\text { - } \quad \text { Often bypassed to the analysis stage } \\
\text { overally loosely embedded into the } \\
\text { practice }\end{array}$ & $\begin{array}{l}\text { - No clear distinction between } \\
\text { reporting and monitoring } \\
\text { although more emphasis was on } \\
\text { reporting } \\
\text { - } \quad \text { Often conducted by site } \\
\text { based/visiting office Quantity } \\
\text { Surveyors without the } \\
\text { involvement of the construction } \\
\text { management team members }\end{array}$ \\
\hline Analysing & $\begin{array}{l}\text { - Mostly qualitative in nature } \\
\text { - Usually interpreting instead of } \\
\text { analysing received information } \\
\text { leading to reactive and not proactive } \\
\text { actions when required }\end{array}$ & $\begin{array}{l}\text { Widespread adoption of } \\
\text { quantitative tools but no } \\
\text { systematic analysis of any } \\
\text { required actions }\end{array}$ \\
\hline
\end{tabular}

\section{Prevalent project time control in practice and shortcomings}

A key theme that emerged from the interviews is that there seems to be a common format used by most of the practitioners interviewed for controlling the time objectives of their projects. The current prevalent practice is described as follows.

The first step normally involves an assessment of the resources available in the company to ensure there are adequate levels of personnel required to deliver the project. The duration of the project is decided at this stage. The methods for making this decision revolve around Cite as: Olawale, Y. and Sun, M. (2015). Construction project control in the UK: current practice, existing problems and recommendations for future improvement. International journal of project management, 33(3), 623-637. 
'assessment from experience' and 'the use of calculations'. This confirms the questionnaire survey result. One problem with the project scheduling and planning lies in the lack of involvement of supply chain partners. Durations of partners' tasks are made based on assumptions, which sometimes are inaccurate.

The second step usually involves the development of a visual representation of the project duration most often using scheduling software packages. The software packages used mainly produces graphical output (Gantt or bar charts). It was revealed that different forms of schedules programmes are developed for different purposes. The different forms of schedules utilised in practice include; tender schedule; contract schedule; target schedule and stage schedule; construction schedule/project master schedule. It was also revealed that the contract schedule is not always handed to the construction site team instead a more ambitious one (target schedule) is utilised. The above can be categorised as the planning phase of the project control cycle, which is only the first step of project control.

The third step of project time control in practice is normally monitoring and reporting. However, there is usually no dedicated monitoring regime and process hence monitoring was ad hoc at best. As a result, there was no due diligence on monitoring to ensure objectiveness leading to non-factual information being reported by site staff. Furthermore, there is no real mechanism in place for reporting progress back from site to the project office. At best, any reporting mechanism in place is often loose and unstructured. This is in line with the argument of Gardiner and Stewart (2000) that even in projects that are progressing well, reporting is often seen as a tedious exercise. Most of the interviewees did not allude to any systematic reporting mechanism. This is not dissimilar to the findings of Shohet and Frydman (2003), which found that $50 \%$ of communication with project counterpart at construction manager level was conducted by informal (verbal) means. This stage of the project time

Cite as: Olawale, Y. and Sun, M. (2015). Construction project control in the UK: current practice, existing problems and recommendations for future improvement. International journal of project management, 33(3), 623-637. 
control appears to move straight from monitoring to the analysing stage bypassing the reporting process. The study notes that the reporting phase of project time control is only loosely incorporated into the overall project control process. Most of the time, it was unclear if time is monitored directly by the project office or progress is reported to the project office by the site management team. It was revealed that the most common time reporting structure in practice during construction projects is through progress meetings, which usually takes place on a weekly basis. Literature also confirms this kind of informal reporting process. Egbu et al (1998) found that meetings between the client and the contractor and meetings between the contractor and subcontractors are the most frequently used "informal planning and control" techniques in construction. This form of reporting structure is obviously not the most effective because necessary control action may be delayed between the interval of meetings. On the other hand, meetings are not being discounted as they are a valuable method of discussing issues relating to the project and are often wider than project time control, but it should not be the main time control reporting avenue. Instead it should just be a supplementary reporting structure or a high-level reporting forum.

The fourth step in the prevailing project time control process in practice is the analysis of the information acquired through monitoring and reporting (albeit loose and unstructured). Apart from a few professionals that alluded to the use of S-curves and earned value analysis during analysing in time control, it seems that the prevailing practice when analysing during time control is a qualitative evaluation of the current progress against the planned progress by marking progress on the project schedules to check if the project is ahead or behind schedule. It was noted that progress are usually marked on the Gantt chart. This reveals that the Gantt chart also doubles up as the prevailing time control tool in addition to it being the prevailing scheduling tool. Hence what happens during the 'analysis step' of the prevailing project time

Cite as: Olawale, Y. and Sun, M. (2015). Construction project control in the UK: current practice, existing problems and recommendations for future improvement. International journal of project management, 33(3), 623-637. 
control process in practice is hardly analysis but interpretation. This is a very simplistic way of analysing during time control because this technique will hardly reveal the underlying reason for a lack of progress or any problem lurking behind that the project team should be wary of.

The fifth and final step revealed, as customary with most control process is 'action'. The study showed that in practice, this appears to be another under-utilised area because since the information generated from the previous step (Analysis) is only interpretation as quantitative analytical tools are rarely utilized to reveal future trends. Hence in practice corrective actions to bring a construction project that is behind schedule back on track are quite often only reactive and usually end up not effective.

\section{Prevalent project cost control in practice and shortcomings}

The cost control process of practitioners interviewed is also quite often similar to one another. The first step is that when a new construction project tender comes into the company, the estimating department prices it. The study revealed that quite often no quantitative estimating method is often used. In the literature Akintoye and Fitzgerald (2000) have found that in the UK, experience based techniques are the three most popular approaches, hence buttressing the finding of this paper that quantitative methods is not often used in practice. The total project cost estimate is usually developed by obtaining quotations from subcontractors and suppliers for the various work package of the project. It was also revealed that that after the tenders have been priced, a common practice is to ensure that every item, service or package in the tender has a cost allocated to it in the hope that this will help control the cost of the package during implementation.

During project cost control the second step involve monitoring and as was the case during control of time no clear distinction between monitoring and reporting appears to exist

Cite as: Olawale, Y. and Sun, M. (2015). Construction project control in the UK: current practice, existing problems and recommendations for future improvement. International journal of project management, 33(3), 623-637. 
although the reversal was noticed (reporting was more structured but monitoring was loose which was the opposite for time control). The study revealed that during cost control the monitoring regime in place doesn't seem robust enough because quite often monitoring does not follow a periodic regime nor utilise a dedicated structure such as computer systems or templates. From the loose monitoring of project cost, the next step revealed involves reporting. As previously mentioned, the reporting mechanism during cost control in practice seems more robust than the monitoring regime. The study revealed that quite often it appears that the monitoring step is bypassed moving straight from planning (determination of the project cost estimate) to cost reporting. This is because many practitioners alluded to the fact that they have site based quantity surveyors tasked mainly with reporting cost to the project office. The site based project team rarely complete cost documents mainly due to the fact that anything to do with cost is considered strictly a quantity surveying matter. A perusal of the literature also revealed that the above is not an isolated finding; Cornick and Osbon (1994) also found that Site Quantity Surveyors saw their prime task as financial reporting to the company and the way they reported cost information was usually ad hoc and varied from site to site within the same organisation.

The fourth step after reporting is analysis but unlike for time control where interpretation is the norm rather than analysis, the study revealed a wider usage of quantitative analytical tools and techniques for cost control. Practitioners widely alluded to the fact they control cost by considering cost and value, using tools like earned value analysis and cost-value comparison to reveal overspend and their causes. The fifth and final step revealed for project cost control is 'action' to control potential cost overrun. Although the analysis step is more detailed than was noticed in time control, it appears there is no systematic way of acting when analyses show the need for action. The study revealed that when the analysis shows any cost overrun

Cite as: Olawale, Y. and Sun, M. (2015). Construction project control in the UK: current practice, existing problems and recommendations for future improvement. International journal of project management, 33(3), 623-637. 
on an activity or work package. The prevalent action involved shuffling cost by finding other work package(s) with an under-spent and reallocating the overrun cost to them.

\section{Recommendations for Future Improvement}

Although there is a lack of previous comprehensive study on the improvement of project control, various authors addressed different aspects of this problem with Charoenngam and Sriprasert (2001) being arguably the most relevant study. The study assessed cost control systems with a view of identifying critical attributes that contributes most to system success. Although, the study focused on cost control, a number of critical attributes were found most of which are similar to this study. Firstly, it was argued that an accurate and realistic estimate can help serve as an effective plan for cost control. Other findings include use of historical data to ensure realistic estimates and budgets can be made. For monitoring, the study recommends that a well-established standard procedure for monitoring can help to smooth the usually difficult task of monitoring. For the analysis process, it was recommended that variance and trend analysis can be performed prior to the completion of each activity to allow for corrective action. For reporting, the study found timely and realistic information in reports as an important attribute of a cost control system.

Howes (2000) argued that variations to the original project are an important part of project management and that it is vitally important that both the time and cost implications of such changes are fully analysed and appreciated by all parties, including the client, from the very outset. Abudayyeh et al (2001) suggested the use of online computer system as a mechanism for improving the quality and timeliness of data and information for construction project control. Moselhi et al (2004) also suggest that web-based system should be used to support

Cite as: Olawale, Y. and Sun, M. (2015). Construction project control in the UK: current practice, existing problems and recommendations for future improvement. International journal of project management, 33(3), 623-637. 
project time and cost control in an integrated way. The developed system demonstrated a number of features that can be regarded as good practice such as project work breakdowm structure, production of earned value-based status reports, utilisation of resource performance indicators to analyse project variances, efficient data sharing and provision of timely generation and distribution of site progress reports.

Egbu et al (1998) made a number of recommendations geared at improving the planning and control processes for construction and ship refurbishments projects. Firstly, the study recommends that early and sustained integration of the key functionaries to the planning and control processes would help to improve planning effectiveness and accuracy. They also recommended that site management should be more informed about early stage planning techniques. Dey et al (1994) recommends the division of a project into controllable work packages through the WBS, for which a project-control technique may be established. They argued that this will make project control more meaningful. Finally, Tuuli et al (2010) recommends the use informal control mechanisms (e.g. mutual objectives setting, open book accounting for GMP packages) during construction projects, to augment formal control.

On the basis of the analysis of interview results and synthesis of literature review, a total of 65 good practice recommendations were developed for the main tasks of project control: planning (28), monitoring (18), reporting (8), and analysing (11). A panel of practitioner experts were invited to evaluate these proposed recommendations using a Delphi method. According to Powell (2003) the success of a Delphi study clearly rests on the combined expertise of the participants who make up the expert panel. It is important to ensure that the right people are chosen for the process. Hence a purposeful process was used for the selection

Cite as: Olawale, Y. and Sun, M. (2015). Construction project control in the UK: current practice, existing problems and recommendations for future improvement. International journal of project management, 33(3), 623-637. 
of participants in this study. The experts for the Delphi panel in this study were purposely selected based on the following factors:

- Must have participated in the earlier interviewing process to ensure they have a background of the research and avoid having to explain the usefulness of the research all over. This will also have the likelihood of increasing their commitment to the process.

- Must have more than 10 years experience in the area of planning and project control/project management of construction projects.

- Must be committed to participate in all the Delphi rounds

A total of eight practitioners agreed to participate in the Delphi process based on these conditions. This was deemed sufficient because firstly, the number represents more than $50 \%$ of those that participated in the preceding interview stage. Secondly, the Delphi process is usually not about statistical representativeness but on group dynamics at reaching a consensus. There is no universal accepted ideal Delphi size. Delphi sizes over the years have ranged from as small as 3 to as large as 98 (cf. Rowe and Wright, 1999). Although, a minimum size of seven or eight have been suggested as being appropriate (Sourani and Sohail, 2014). Thirdly and more importantly, according to Powell (2003), the Delphi sample is assessed on the qualities of the expert panel rather than its number. The details of the experts are shown in Table 10. These experts hold senior positions in the planning, projects/programme departments of their organisations, which are very relevant to the study area. Quite a few of them were also directors responsible for the project department, which would normally involve the planning and project control section. These experts were also very experienced practitioners with six of the eight experts having more than 25 years of

Cite as: Olawale, Y. and Sun, M. (2015). Construction project control in the UK: current practice, existing problems and recommendations for future improvement. International journal of project management, 33(3), 623-637. 
experience. The total experience of the experts was 227 years (average experience of 28 years). The experts were made-up of contractors and consultants which provided a good mix as synonymous to the previous interviewing stage.

Table 10: Information on participants of the Delphi process

\begin{tabular}{lll}
\hline Position of expert & $\begin{array}{l}\text { Years of } \\
\text { experience }\end{array}$ & Company type \\
\hline Senior general project manager & 30 & Main contractor \\
Senior programme manager & 11 & Consortium \\
Director & 25 & Contractor \\
Director & 28 & Consultant \\
Planning director & 28 & Main contractor \\
Director & 40 & Main contractor \\
Head of Project Planning & 20 & Main contractor \\
Director & 45 & Consultant \\
\hline
\end{tabular}

The main objective of the Delphi exercise, which was conducted in two rounds using questionnaires, was to establish the degree of relevance and importance for the 65 proposed good practices. During the first round, each expert was asked to assess the significance of each practice in helping the relevant project control task independently, using a Likert scale 'critical', 'important', 'helpful' or 'unimportant'. This round was titled 'initial evaluation'. After this round the returned Delphi questionnaires were analysed and the results were posted back to the respondents for reconsideration. It should be pointed out that in order to avoid the situation where it seems the respondents were being forced to change their mind. It was clearly stated on the questionnaire that expert should reconsider their rating in line with the majority rating only where deemed fit. The second round of Delphi was titled -'reevaluation'. Percentages was used to present how the practices were rated by indicating the percentage of expert that had rated a practice as significant, important, helpful or unimportant, with a new column now provided for practitioners reconsidered rating. The returned Delphi questionnaires were again analysed and the iteration was stopped after the second round as there would be no further benefit derived from more Delphi rounds due to Cite as: Olawale, Y. and Sun, M. (2015). Construction project control in the UK: current practice, existing problems and recommendations for future improvement. International journal of project management, 33(3), 623-637. 
consensus having been reached. Consensus was deemed to have been reached when the level of agreement on a practice becomes a majority, that is, greater than 50\%. According Gracht (2012), the determination of consensus by level of agreement is particularly meaningful if ordinal data such as Likert scales are used for the degree of agreement, as is the case for the Delphi's questionnaire of this study. .

The result of both rounds of Delphi is summarised in the following.

- First round of Delphi process: The analysis of the responses showed that less than $50 \%$ of the respondents agreed on the significance ('critical' or 'important' or 'helpful' or 'unimportant') of 8 of practices, while $50 \%-70 \%$ of the experts agreed on the significance of 44 of the practices and more than $70 \%$ of the experts agreed on the significance only on 13 of the practice during this round. Furthermore the analysis showed the majority view on the practices are as follows; 21 practices were deemed critical by the experts, 33 were deemed important, 11 practices deemed helpful and none of the 65 practices was rated by a majority as unimportant. This round of Delphi has obviously revealed that although all 65 practices were deemed useful for project cost and time control but 8 of the 65 practices had less than $50 \%$ of the experts agreeing on their significance. Since the whole aim of the Delphi process is to see if majority of the experts can agree on as many practices as possible it was deemed that a second round of Delphi would be needed.

- Second round of the Delphi process: The questionnaire was redesigned with an additional column showing the majority rating given to a practice. The 4-scale Likert scale option was then provided next to the majority rating for experts to reconsider their rating in line with the majority view where deemed necessary. The results practice, existing problems and recommendations for future improvement. International journal of project management, 33(3), 623-637. 
showed that 21 practices were still considered as critical, 33 practices were still considered important and 11 practices as helpful but importantly all the 65 practices now have at least $50 \%$ of the experts agreeing on their significance hence it was deemed that consensus had been reached on the significance of all the good practices put forward to the expert panel. Table 11 shows shift of consensus during the two rounds of Delphi, where it is evident that some experts changed their minds; as a result, the level of agreement below 50\% has now dropped from 8 practices to zero. The table shows that $50 \%-70 \%$ of experts now have the same opinion on about 22 of the practices. This is a massive turnaround as this group was the majority during the first round process but some experts have now changed their opinion on a number of the practices aligning their rating with the rest of the group. This round of Delphi has successfully achieved the quest to get the highest proportion of experts to agree on the significance of a high number of the practices. From the table it would be seen that the tide has turned during this round as more than $70 \%$ of experts now agree on the significance of 43 of the 65 practices as opposed to just 13 practices during the earlier round. This is a $230 \%$ improvement on the first round. This round of Delphi has helped achieved consensus as all the 65 practices now have a majority view of $50 \%$ or

more. Hence it was deemed that consensus had been reached on the significance of all the good practices put forward to the expert panel. The reaching of majority agreement for all the 65 good practice recommendations by expert practitioners after only two rounds of Delphi is a good indication of their relevance in addressing some of the existing problems of project control practice revealed during the study.

Cite as: Olawale, Y. and Sun, M. (2015). Construction project control in the UK: current practice, existing problems and recommendations for future improvement. International journal of project management, 33(3), 623-637. 
Table 11: Improvement of consensus between Delphi rounds

\begin{tabular}{lll}
\hline $\begin{array}{l}\text { Level of agreement } \\
\text { among experts }\end{array}$ & $1^{\text {st }}$ round & $2^{\text {nd }}$ round \\
Delphi & Delphi \\
\hline$<50 \%$ & 8 & 0 \\
$50 \%-70 \%$ & 44 & 22 \\
$>70 \%$ & 13 & 43 \\
\hline
\end{tabular}

The 65 proposed improvement advices on good practices of project control and the degree of consensus achieved amongst the expert, as well as the agreed level of significance to the project control process are presented in Tables 12-15.

Table 12 Good practice recommendations for Planning

\begin{tabular}{|c|c|c|c|}
\hline Description of practice & $\begin{array}{l}1^{\text {st }} \text { round } \\
\text { Delphi }\end{array}$ & $\begin{array}{l}2^{\text {nd }} \text { round } \\
\text { Delphi }\end{array}$ & $\begin{array}{l}\text { Level of } \\
\text { significance }\end{array}$ \\
\hline Development of a programme of works for the project time estimate & $100 \%$ & - & Critical \\
\hline Ensuring the programme of works is realistic & $87.5 \%$ & $100 \%$ & Critical \\
\hline Setting of tangible milestones within the developed programme & $62.5 \%$ & $87.5 \%$ & Critical \\
\hline Establishing a clearly identifiable critical path on the programme (schedule) & $87.5 \%$ & $87.5 \%$ & Critical \\
\hline $\begin{array}{l}\text { Knowledge of the impact/relationship of not finishing on time and increased } \\
\text { project cost }\end{array}$ & $75 \%$ & $87.5 \%$ & Critical \\
\hline $\begin{array}{l}\text { Involvement of the subcontractor early for advice and input when developing } \\
\text { the programme }\end{array}$ & $50 \%$ & $62.5 \%$ & Critical \\
\hline Embracing a holistic approach during the development of the programme & $50 \%$ & $62.5 \%$ & Critical \\
\hline $\begin{array}{l}\text { Ensuring there is proper handover of the tender from the tender Quantity } \\
\text { Surveyor (QS) to the Project QS to ensure understanding of how the job is } \\
\text { priced }\end{array}$ & $50 \%$ & $62.5 \%$ & Critical \\
\hline $\begin{array}{l}\text { Utilisation of a project planner that has an appreciation of the construction } \\
\text { process }\end{array}$ & $50 \%$ & $50 \%$ & Critical \\
\hline Making sure the cost budget is realistic at all times & $50 \%$ & $50 \%$ & Critical \\
\hline Utilisation of historical data when developing a programme of works & $75 \%$ & $100 \%$ & Important \\
\hline $\begin{array}{l}\text { Ensuring all activities/packages in the project have their allocated cost for } \\
\text { carrying out the works }\end{array}$ & $75 \%$ & $100 \%$ & Important \\
\hline Making sure the project team understands the cost budget & $62.5 \%$ & $100 \%$ & Important \\
\hline Building in some flexibility into the programme if possible & $87.5 \%$ & $87.5 \%$ & Important \\
\hline Development of the programme to a great detail & $50 \%$ & $87.5 \%$ & Important \\
\hline Ensuring that cost and time control is always integrated & $50 \%$ & $87.5 \%$ & Important \\
\hline Having an agreed price with the client that will be used for variations & $62.5 \%$ & $75 \%$ & Important \\
\hline $\begin{array}{l}\text { Ensuring the programme and cost estimate are updated as the design evolve } \\
\text { until the design sign off }\end{array}$ & $62.5 \%$ & $75 \%$ & Important \\
\hline $\begin{array}{l}\text { Ensuring the project cost and time control process is consistent across the } \\
\text { company }\end{array}$ & $62.5 \%$ & $75 \%$ & Important \\
\hline $\begin{array}{l}\text { Making sure there is enough time from tender acceptance to starting on site in } \\
\text { order to properly plan the work }\end{array}$ & $50 \%$ & $75 \%$ & Important \\
\hline $\begin{array}{l}\text { Establishment of a structure within the project control process aligning the } \\
\text { cost breakdown structure with the work breakdown structure }\end{array}$ & $37.5 \%$ & $62.5 \%$ & Important \\
\hline $\begin{array}{l}\text { Making sure the project team members are trained in the science of project } \\
\text { cost and time control }\end{array}$ & $37.5 \%$ & $62.5 \%$ & Important \\
\hline
\end{tabular}

Cite as: Olawale, Y. and Sun, M. (2015). Construction project control in the UK: current practice, existing problems and recommendations for future improvement. International journal of project management, 33(3), 623-637. 


\begin{tabular}{llll}
\hline $\begin{array}{l}\text { Having a separate target programme that is more ambitious than the } \\
\text { contractual programme }\end{array}$ & $50 \%$ & $50 \%$ & Important \\
$\begin{array}{l}\text { Ensuring there is a procurement strategy for buying all packages in the project } \\
\text { at the tender stage }\end{array}$ & $37.5 \%$ & $50 \%$ & Important \\
$\begin{array}{l}\text { Development of the cost estimate/budget using quantifiable metrics (e.g. } \\
\text { cost/m2 of brick laid etc.) }\end{array}$ & $37.5 \%$ & $50 \%$ & Important \\
$\begin{array}{l}\text { Testing the viability of the programme using 4-d (3-d with a programme of } \\
\text { works) virtual reality model }\end{array}$ & $62.5 \%$ & $87.5 \%$ & Helpful \\
$\begin{array}{l}\text { Development of the programme using quantifiable metrics (e.g. bricks } \\
\text { laid/m } / \text { day) }\end{array}$ & $50 \%$ & $62.5 \%$ & Helpful \\
Utilisation of an agreed maximum price contract when possible & $37.5 \%$ & $50 \%$ & Helpful \\
\hline
\end{tabular}

Table 13 Good practice recommendations for Monitoring

\begin{tabular}{|c|c|c|c|}
\hline Description of practice & $\begin{array}{l}1^{\text {st }} \text { round } \\
\text { Delphi }\end{array}$ & $\begin{array}{l}2^{\text {nd }} \text { round } \\
\text { Delphi }\end{array}$ & $\begin{array}{l}\text { Level of } \\
\text { significance }\end{array}$ \\
\hline $\begin{array}{l}\text { Making sure there is a regular monitoring regime (e.g. weekly/monthly) } \\
\text { embedded in the project }\end{array}$ & $75 \%$ & $87.5 \%$ & Critical \\
\hline Monitoring the project time progress against the critical path at all times & $75 \%$ & $87.5 \%$ & Critical \\
\hline Constantly monitoring design changes to avoid escalation & $62.5 \%$ & $87.5 \%$ & Critical \\
\hline $\begin{array}{l}\text { Specifying clearly what the deliverables of the project cost and time control } \\
\text { will be in order to aid monitoring }\end{array}$ & $50 \%$ & $62.5 \%$ & Critical \\
\hline Constantly monitoring against key milestones & $50 \%$ & $62.5 \%$ & Critical \\
\hline $\begin{array}{l}\text { Proper knowledge of and agreeing the time and cost implication of any } \\
\text { variation whenever possible before going ahead }\end{array}$ & $100 \%$ & - & Important \\
\hline $\begin{array}{l}\text { Ensuring there is a project cost and time control manual that the site } \\
\text { monitoring team can refer to, if at a loss about the project control process }\end{array}$ & $100 \%$ & - & Important \\
\hline $\begin{array}{l}\text { Making sure the site personnel are trained in the project cost and time } \\
\text { control monitoring process }\end{array}$ & $87.5 \%$ & $87.5 \%$ & Important \\
\hline $\begin{array}{l}\text { Having a system in place that checks submitted subcontractors cost against } \\
\text { actual work done/payment due }\end{array}$ & $87.5 \%$ & $87.5 \%$ & Important \\
\hline $\begin{array}{l}\text { Monitoring that works are procured within the allocated allowance in the } \\
\text { tender }\end{array}$ & $87.5 \%$ & $87.5 \%$ & Important \\
\hline $\begin{array}{l}\text { Daily/frequent monitoring of cost and time to identify potential risk areas } \\
\text { early on }\end{array}$ & $75 \%$ & $75 \%$ & Important \\
\hline $\begin{array}{l}\text { Making sure the people monitoring from the office regularly visit the project } \\
\text { site }\end{array}$ & $75 \%$ & $75 \%$ & Important \\
\hline $\begin{array}{l}\text { Ensuring there is regular project cost and time control progress meetings } \\
\text { involving planners, QS and the Site management team }\end{array}$ & $75 \%$ & $75 \%$ & Important \\
\hline $\begin{array}{l}\text { Ensuring there is a system for monitoring efficiency of labour as part of the } \\
\text { cost and time control process }\end{array}$ & $62.5 \%$ & $75 \%$ & Important \\
\hline $\begin{array}{l}\text { Ensuring there is an independent regular monitoring of the project by } \\
\text { someone apart from the site manager }\end{array}$ & $50 \%$ & $75 \%$ & Important \\
\hline Constantly monitoring short term and medium term cash flows & $50 \%$ & $75 \%$ & Important \\
\hline Utilising the cash flow as a first monitoring tool & $75 \%$ & $75 \%$ & Helpful \\
\hline Monitoring the project critical path using the S-curve & $62.5 \%$ & $62.5 \%$ & Helpful \\
\hline
\end{tabular}

Cite as: Olawale, Y. and Sun, M. (2015). Construction project control in the UK: current practice, existing problems and recommendations for future improvement. International journal of project management, 33(3), 623-637. 
Table 14 Good practice recommendations for Reporting

\begin{tabular}{|c|c|c|c|}
\hline Description of practice & $\begin{array}{l}1^{\text {st }} \text { round } \\
\text { Delphi }\end{array}$ & $\begin{array}{l}2^{\text {nd }} \text { round } \\
\text { Delphi }\end{array}$ & $\begin{array}{l}\text { Level of } \\
\text { significance }\end{array}$ \\
\hline $\begin{array}{l}\text { Making sure that the cost and time status information being reported is up- } \\
\text { to-date }\end{array}$ & $87.5 \%$ & $100 \%$ & Critical \\
\hline Making sure the reporting is always honest and true & $62.5 \%$ & $87.5 \%$ & Critical \\
\hline Regular reporting of the project cost and time status & $50 \%$ & $87.5 \%$ & Critical \\
\hline Accurately recording information & $50 \%$ & $62.5 \%$ & Critical \\
\hline $\begin{array}{l}\text { Ensuring there is an open and trusting relationship between the site } \\
\text { management team and office team to ensure reporting from site is honest } \\
\text { and accurate }\end{array}$ & $50 \%$ & $50 \%$ & Critical \\
\hline $\begin{array}{l}\text { Presentation of the report using quantitative tools ( e.g. graphs, curves and } \\
\text { histograms) }\end{array}$ & $50 \%$ & $87.5 \%$ & Important \\
\hline Avoiding the use of complex IT manipulations for reporting & $50 \%$ & $87.5 \%$ & Important \\
\hline $\begin{array}{l}\text { Incorporating qualitative explanation into reports in addition to quantitative } \\
\text { graphs and curves, so that the reason behind results can be properly } \\
\text { understood }\end{array}$ & $50 \%$ & $75 \%$ & Important \\
\hline
\end{tabular}

Table 15 Good practice recommendations for Analysing

\begin{tabular}{|c|c|c|c|}
\hline Description of practice & $\begin{array}{l}1^{\text {st }} \text { round } \\
\text { Delphi }\end{array}$ & $\begin{array}{l}2^{\text {nd }} \text { round } \\
\text { Delphi }\end{array}$ & $\begin{array}{l}\text { Level of } \\
\text { significance }\end{array}$ \\
\hline $\begin{array}{l}\text { Having an independent personnel at next higher management level to assess } \\
\text { the reports to ascertain if it is optimistic, factual or pessimistic }\end{array}$ & $50 \%$ & $62.5 \%$ & Critical \\
\hline $\begin{array}{l}\text { Forecasting the completion time and cost at completion as part of the } \\
\text { analysing activity during project controls }\end{array}$ & $50 \%$ & $75 \%$ & Important \\
\hline $\begin{array}{l}\text { Ensuring that people are inclined to releasing information on time especially } \\
\text { cost information to aid analysis }\end{array}$ & $50 \%$ & $75 \%$ & Important \\
\hline $\begin{array}{l}\text { Utilisation of cost-value comparison when analysing during project cost and } \\
\text { time control }\end{array}$ & $37.5 \%$ & $50 \%$ & Important \\
\hline Ensuring cost and time are integrated during analysis & $37.5 \%$ & $50 \%$ & Important \\
\hline Analysing performance using S-curves & $75 \%$ & $87.5 \%$ & Helpful \\
\hline $\begin{array}{l}\text { Focusing on the efficiency of labour when analysing in project cost and time } \\
\text { control }\end{array}$ & $50 \%$ & $75 \%$ & Helpful \\
\hline $\begin{array}{l}\text { Modelling cost and time when analysing using a } 5 \text {-d model to visualise (how } \\
\text { the design develops (3-d), how time is being expended (4-d) and how the } \\
\text { cost develops (5-d) }\end{array}$ & $50 \%$ & $75 \%$ & Helpful \\
\hline $\begin{array}{l}\text { Having an individual or single department responsible for both cost and time } \\
\text { control (e.g. a project control manager rather than having planning } \\
\text { department and a QS department each controlling time and cost separately) }\end{array}$ & $50 \%$ & $75 \%$ & Helpful \\
\hline Conducting trend analysis to identify trends early on & $62.5 \%$ & $62.5 \%$ & Helpful \\
\hline $\begin{array}{l}\text { Determination of the cost for the period, value and earned value and the } \\
\text { cumulative so far when analysing project progress }\end{array}$ & $50 \%$ & $62.5 \%$ & Helpful \\
\hline
\end{tabular}

Cite as: Olawale, Y. and Sun, M. (2015). Construction project control in the UK: current practice, existing problems and recommendations for future improvement. International journal of project management, 33(3), 623-637. 
The first observation from the above tables is that planning had the most good practice recommendations as well as the most practices where the level of significance were agreed as being critical to the project control process. This buttresses the thinking of Duhig (1993) that an effective project control system relies on two fundamental components: (1) a plan against which progress can be measured (and new circumstances evaluated); and (2) timely and accurate information about what is actually happening (or likely to happen) on the project. Planning tends to receive more attention by both researchers and practitioners than do the other project control activities.

It is also worthy of note that, as previously mentioned, these good practice recommendations are in groups according to the level of relevance agreed by the majority of the experts. Within each group, they are ranked according to the final degree of agreement reached amongst the experts. For the 'critical' group, the ranking order reflects the significance of recommendations in the view of the experts. However, this may not be the case for the 'important' and 'helpful' groups. For example, in Table 12, all 8 experts rated 'Utilisation of historical data when developing a programme of works", "Ensuring all activities/packages in the project have their allocated cost for carrying out the works" and "Making sure the project team understands the cost budget" as 'important'; so they had 100\% agreement. The next recommendation "Building in some flexibility into the programme if possible" had $87.5 \%$ agreement as 'important'. However, the one expert, who did not agree with the rating, actually rated it as 'critical'. Therefore, this recommendation is as important as, even more important than, the top three recommendations in this 'important' group. There are numerous other similar examples.

Cite as: Olawale, Y. and Sun, M. (2015). Construction project control in the UK: current practice, existing problems and recommendations for future improvement. International journal of project management, 33(3), 623-637. 
Finally, these good practice recommendations are not meant to be 'how-to' guides. Instead, most of them outline what should be done at each project control stage. Practitioners should review these recommendations, and then determine how the task can be best carried out for their projects and what tools might be required for that particular activity. It is not necessary that all these recommendations should be applied to all projects. Equally, these recommendations might not be sufficient for some projects, where other actions may be required. It is expected that the current time and cost control practice can be improved if these recommendations are adopted in construction projects.

\section{Conclusions}

This UK based study has identified issues most relevant to the contemporary project control practice in the country. It is evident that there is a great deal of similarity between UK contractors and consultants on various issues relating to their cost and time control practices. For example, there was mostly no statistical difference in how the duration and cost of construction projects are determined. However it appears that contractors favour the use of calculations and a combination of both calculations and experience to estimate the time duration of their construction projects while consultants mostly utilise experience only. The reason behind this may be due to the fact that contractors would normally use past experience to evaluate project duration in addition to using techniques based on calculations in order to ensure accuracy. Most consultants on the other hand seem to embrace the use of experience when estimating the time duration of their construction project. The reason for this can be due to the fact that consultants are normally involved in estimation of time duration for the client at the early stages of a project. At that stage the availability of information is normally

Cite as: Olawale, Y. and Sun, M. (2015). Construction project control in the UK: current practice, existing problems and recommendations for future improvement. International journal of project management, 33(3), 623-637. 
limited and the client would only require a rough idea of the time duration that their proposal would take.

The study found a strong similarity in the most commonly used techniques and software packages by both groups for planning/time control and cost control. The classical project control techniques and the most popular software packages still remains the most commonly used by contractors and consultants in the UK. Gantt chart and the Critical path method (CPM) are the most popular choices; with the Gantt chart used more for planning while the CPM is more of a control tool. The most widely used software packages are the Microsoft projects and the Asta power project. The most commonly used technique for cost control is the cost-value reconciliation method while in-house/bespoke cost estimate and control systems are used by more companies. A usual accusation made against tools and techniques is that they may sometime not be utilised by those it was made for; this does not appear to be the case in the UK construction industry. The study revealed that the overwhelming majority of practitioners in the UK apply relevant project control techniques on their projects with 93\% of contractors, for example, indicating that they always apply cost control on the projects. It was however revealed that the application of cost control is more prevalent than time control by both contractors and consultants.

Despite the obvious application of project control practice, a number of deficiencies were identified. The most important problem is the fact that quite often project control does not integrate cost and time during the project control process. Since cost and time are usually intrinsically connected, for example delaying or compressing the completion time of a project would usually have a cost implication, controlling cost and time separately can hardly be

Cite as: Olawale, Y. and Sun, M. (2015). Construction project control in the UK: current practice, existing problems and recommendations for future improvement. International journal of project management, 33(3), 623-637. 
effective. Another revelation of the study was the sometimes ad hoc nature of key stages of the project control process. For example, during the planning stage, the study revealed an over reliance on experience instead of formal planning methods for time control. There was also the use of multiple and inconsistent scheduling targets as well as a variety of tools with little standardization of usage across the industry. For cost control at this stage, it was evident that estimates are rarely developed from basis with the amalgamation of quotations from various work packages. Monitoring is a weak link for both time and cost control. There is a lack of reliable systems to capture up to date information on work progress on site. Control moves from planning straight to reporting with minimal involvement of the site management personnel. Reporting during the time control process was found to be loosely embedded into the overall project control process with no formal reporting mechanism between the site and the office. During the cost control process it was often conducted by site-based/visiting office Quantity Surveyors without the involvement of the site team. Analysis for time control is mostly qualitative; while for cost control although quantitative tools are more widely used, the process is not systematic.

In response to the revelation of existing shortcomings, the study has developed a set of 65 good practice recommendations through extensive interaction with practitioners. These recommendations are aimed at improving the practice of key project control tasks, including planning, monitoring, reporting and analysis. They have received wide endorsement from practitioners through a Delphi process, with $83 \%$ of the good practices considered by majority of the experts as either critical or important in aiding project control and the remaining $17 \%$ considered helpful. This is a good indication of their relevance in addressing the existing problems of project control practice. However, it is important to note that this list

Cite as: Olawale, Y. and Sun, M. (2015). Construction project control in the UK: current practice, existing problems and recommendations for future improvement. International journal of project management, 33(3), 623-637. 
is not exhaustive. In addition, although the Delphi process serves as a validation exercise to ascertain the significance of the recommendations, further research may be required to investigate their effectiveness during the project control process.

\section{References}

Abdul-Rahman, H., Berawi, M., Berawi, A., Mohamed, O., and Othman, M., Yahya, I., 2006. "Delay mitigation in the Malaysian construction industry." Journal of Construction Engineering and Management, 132(2), 125 - 133.

Abudayyeh, O., Temel, B., Al-Tabtabai, H., and Hurley, B., 2001. "An Intranet-based cost control system." Advances in Engineering Software, 32(2), 87 - 94.

Acebes F., Pajares J., Galán J.M., López-Paredes A., 2014. “A new approach for project control under uncertainty. Going back to the basics". International Journal of Project Management 32(3) 423-434

Aibinu, A., and Jagboro, G., 2002. "The effects of construction delays on project delivery in Nigerian construction industry." International Journal of Project Management, 20(8), 593599.

Akintoye, A. and Fitzgerald, E., 2000. "A survey of current cost estimating practices in the UK." Construction Management and Economics, 18(2), 161-172.

Aliverdi, R., Naeni, L., Salehipour, A., 2014. "Monitoring project duration and cost in a construction project by applying statistical quality control charts." International Journal of Project Management 31(3) 411-423.

Al-Momani, A., 2000. "Construction delay: a quantitative analysis.” International Journal of Project Management, 18(1), 51-59.

Cite as: Olawale, Y. and Sun, M. (2015). Construction project control in the UK: current practice, existing problems and recommendations for future improvement. International journal of project management, 33(3), 623-637. 
Alshawi, M., and Hassan, Z., 1999. "Integrated models for construction planning: object flow and relationship" Engineering, Construction and Architectural Management, 6(2), 197-212. Assaf, S. and Al-Hejji, S., 2006. "Causes of delay in large construction projects." International Journal of Project Management, 24(4), 349-357.

Assaf, S., Al- Khaliil, M., and Al-Hazmi, M., 1995. "Causes of delay in large building construction projects." Journal of Management in Engineering, 11(2), 45 - 50.

Association for Project Management, 2006. APM Body of Knowledge (5 ${ }^{\text {th }}$ edition), Association for Project Management, Princes Risborough.

Association for Project Management, 2010. Introduction to Project Control, Association for Project Management, Princes Risborough.

Baguley, P., 2008. Project Management, Hodder Education, London.

Barraza, G., Bueno, R., 2007. "Probabilistic control of project performance using control limit curves." Journal of Construction Engineering and Management, 133(12), 957 - 965.

Benjaoran, V., 2009. “A cost control system development: A collaborative approach for small and medium-sized contractors.” International Journal of Project Management, 27(3), 270 277.

Chang, A., 2002. "Reasons for cost and schedule increase for engineering design projects." Journal of Management in Engineering, 18(1), 29-36.

Charoenngam, C., and Sriprasert, E., 2001. "Assessment of cost control system: a case study of Thai construction organisations." Engineering, Construction and Architectural Management, 8 (8/6), $368-380$.

Chartered Institute of Building (CIOB), 2008. A Research on Managing the Risk of Delayed Completion in the $21^{\text {st }}$ Century, CIOB, Ascot.

Cite as: Olawale, Y. and Sun, M. (2015). Construction project control in the UK: current practice, existing problems and recommendations for future improvement. International journal of project management, 33(3), 623-637. 
Cheng, Y., 2014. "An exploration into cost-influencing factors on construction projects.” International Journal of Project Management, 35(5), 850 - 860.

Cho, K., Hong, T., and Hyun, C., 2010. "Integrated schedule and cost model for repetitive construction process.” Journal of Management in Engineering, 26(2), 78 - 88.

Cooke, B., and Williams, P., 2004. Construction planning programming and control, Blackwell, Oxford.

Cornick, T. and Osbon, K., 1994. “A study of the contractor's quantity surveying practice during the construction process." Construction Management and Economics, 12(2), 107 111.

Dey, P., Tabucanon, M., and Ogunlana, S., 1994. "Planning for project control through risk analysis: a petroleum pipeline-laying project." International Journal of Project Management 12(1), pp. 23-33.

Duhig B., 1993. Project Control, NCC Blackwell Ltd, Oxford, England.

Egan, J., 1998. Rethinking construction: The report of the construction task force, Department of Trade and Industry, London.

Egbu, C., Young, B., Torrance, V., 1998. "Planning and control processes and techniques for refurbishment management.” Construction Management and Economics, 16(3), 315-325.

Falco, M., and Macchiaroli, R., 1998. "Timing of control activities in project planning." International Journal of Project Management, 16(1), 51 - 58.

Fena-Mora, F., and Li, M., 2001. "Dynamic planning and control methodology for design/build fast-track construction projects." Journal of Construction Engineering and Management 127(1), 1-17.

Flyvbjerg B., Holm, M., and Buhl, S., 2003. "How common and how large are cost overruns in transport infrastructure projects?" Transport Reviews, 23(1), 71-88.

Cite as: Olawale, Y. and Sun, M. (2015). Construction project control in the UK: current practice, existing problems and recommendations for future improvement. International journal of project management, 33(3), 623-637. 
Frimpong, Y., Oluwoye, J., and Crawford, L., 2003. "Causes of delay and cost overruns in construction of groundwater projects in a developing country: Ghana as a case study." International Journal of Project Management, 21(5), 321-326.

Gardiner, P. and Stewart K., 2000. "Revisiting the golden triangle of cost time and quality: the role of NPV in project control success and failure." International Journal of Project Management, 18(4), 251-256.

Gorog, M., 2009. "A comprehensive model for planning and controlling contractor cashflow.” International Journal of Project Management, 27(5), 481 - 492.

Gracht, H., 2012. "Consensus measurement in Delphi studies: Review and implications for future quality assurance." Technological Forecasting \& Social Change 79 (2012) 1525-1536. Haponava, T. and Al-jibouri, S., 2010. "Influence of process performance during the Construction Stage on Achieving End-project Goals." Construction Management and Economics, 28(8), $853-869$.

Heldman, K., 2005. Project manager's spotlight on risk management, Neil Edde, Alameda. Hoffman, G., Thal, A., Webb, T., and Weir, J., 2007. "Estimating performance time for construction projects.” Journal of Management in Engineering, 23(4), 193 - 199.

Howes, R., 2000. "Improving the performance of Earned Value Analysis as construction project management tool." Engineering, Construction and Architectural Management, 7 (4), $399-4111$.

Hsieh, T., Lu, S., and Wu, C., 2004. "Statistical analysis of causes for change orders in metropolitan public works.” International Journal of Project Management, 22(8), 679-686. Iyer, K. and Jha, K., 2005. "Factors affecting cost performance evidence from Indian construction projects." International Journal of Project Management, 23(4), 283-295.

Cite as: Olawale, Y. and Sun, M. (2015). Construction project control in the UK: current practice, existing problems and recommendations for future improvement. International journal of project management, 33(3), 623-637. 
Jennings, W., 2012. "Why costs overrun: Risk, optimism and uncertainty in budgeting for the London 2012 Olympic Games.” Construction Management and Economics, 30(6), 455 - 462. Jung, Y., and Kang, S., 2007. "Knowledge-based standard progress measurement for integrated cost and schedule performance control." Journal of Construction Engineering and Management, 133(1), 10-21.

Kaka, A., 1999. "The development of a benchmark model that uses historical data for monitoring the progress of current construction projects." Engineering, Construction and Architectural Management, 6(3), 256-266.

Kaliba, C. Muya, M., and Mumba K., 2009. "Cost escalation and schedule delays in road construction projects in Zambia." International Journal of Project Management, 27(5), 522531.

Kaming, P., Olomolaiye, P., Holt, G., and Harris, F., 1997. "Factors influencing construction time and cost overruns on high-rise projects in Indonesia." Construction Management and Economics, 15(1), 83-94.

Khamooshi, H., and Golafshani, H., 2014. "EDM: Earned Duration Management, a new approach to schedule performance management and measurement." International Journal of Project Management 32(6) 1019-1041.

Kim, S., and Liu, L., 2007. "Cost information models for managing multiple projects." Journal of Construction Engineering and Management, 133(12), 966 - 974.

Kirk, R., 1999. Statistics: An Introduction, Harcourt Brace college publishers, Forth Worth. Koushki, P., Al-Rashid, K., and Kartam, N., 2005. "Delays and cost increases in the construction of private residential projects in Kuwait." Construction Management and Economics, 23(3), 285-294.

Cite as: Olawale, Y. and Sun, M. (2015). Construction project control in the UK: current practice, existing problems and recommendations for future improvement. International journal of project management, 33(3), 623-637. 
Kumaraswamy, M., and Chan, W., 1998. "Contributors to construction delays." Construction Management and Economics, 16(1), 17-29.

Lee, J., 2008. "Cost overrun and cause in Korean social overhead capital projects: Roads, rails, airports, and ports." Journal of Urban Planning and Development, 134 (2), 59 - 62.

Mansfield, N., Ugwu, O., and Doran, T., 1994. "Causes of delay and cost overruns in Nigerian construction projects.” International Journal of Project Management, 12(4), 254260.

Marco, A., Briccallero, D., and Rafele, C., 2009. "Cost and schedule monitoring of industrial building projects: Case study." Journal of Construction Engineering and Management, $135(9), 853-862$.

Mckim, R. and Hegazy, T., 2000. "Project Performance Control in Reconstruction Projects." Journal of Construction Engineering and Management, 126(2), 137 - 141.

Odeck, J., 2004. "Cost overruns in road construction - what are their sizes and determinants?" Transport Policy, 11(1), 45 -53.

Project Management Institute, 2008. A Guide to the Project Management Body of Knowledge (PMBOK Guide), $4^{\text {th }}$ Edn. Project Management Institute, Newtown Square.

Ritchie, J., Spencer, L., O’Connor W., 2003. "Carrying out qualitative analysis”, in: Ritchie, J., Lewis, J. (eds.), Qualitative Research Practice: A Guide for Social Science Students and Researchers. SAGE publications, London, pp. 219-262.

Rowe, G., and Wright, R., 1999. "The Delphi technique as a forecasting tool: issues and analysis.” International Journal of Forecasting, 15(4), 353-375.

Rozenes, S., Vitner, G., and Spraggett, S., 2004. "MPCS: Multidimensional Project Control System.” International Journal of Project Management, 22(2), 109 - 118.

Cite as: Olawale, Y. and Sun, M. (2015). Construction project control in the UK: current practice, existing problems and recommendations for future improvement. International journal of project management, 33(3), 623-637. 
Ruskin A., Estes W., 1995. What every Engineer should know about project management. Marcel Dekker, Inc., New York.

Moselhi, O., Li, J., and Alkass, S., 2004. "Web-based integrated project control system." Construction Management and Economics, 22, 35 - 46.

Naeni, L., Shadrokh, S., Salehipour, A., 2011 "A fuzzy approach for the earned value management.” International Journal of Project Management, 29(6) 764-772.

Olawale, Y., and Sun, M., 2010. "Cost and time control of construction projects: Inhibiting factors and mitigating measures in practice." Construction Management and Economics, 28 (5), $509-526$.

Olawale, Y., and Sun, M., 2013. 'PCIM: Project Control and Inhibiting-Factors Management Model." Journal of Management in Engineering, 29(1), 60-70.

Shane, J., Molenaar, K., Anderson, S., and Schexnayder, C., 2009. “Construction project cost escalation factors.” Journal of Management in Engineering, 25(4), 221 - 229.

Shehu Z., Endut I.R., Akintoye A., Holt G.D., 2014. "Cost overrun in the Malaysian construction industry projects: A deeper insight". International Journal of Project Management, in press, DOI: 10.1016/j.ijproman.2014.04.004

Shohet, I. and Frydman, S., 2003. "Communication patterns in construction at construction manager level.” Journal of Construction Engineering and Management, 129(5), 570 - 577.

Sohail, M., Miles, D., and Cotton, A., 2002. "Developing monitoring indictors for urban micro contracts in South Asia.” International Journal of Project Management, 20 (8), pp. 583-591.

Sourani, A., and Sohail, M., 2014. "The Delphi Method: Review and Use in Construction Management Research." International Journal of Construction Education and Research, in press, DOI: 10.1080/15578771.2014.917132

Cite as: Olawale, Y. and Sun, M. (2015). Construction project control in the UK: current practice, existing problems and recommendations for future improvement. International journal of project management, 33(3), 623-637. 
Sun, M. and Meng, X., 2009. Taxonomy for change causes and effects in construction projects. International Journal of Project Management, 27(6), 560-572.

Tuuli, M., Rowlinson, S., and Koh, T., (2010) "Dynamics of control in construction project teams." Construction Management and Economics, 28(2), 189 - 202.

Cite as: Olawale, Y. and Sun, M. (2015). Construction project control in the UK: current practice, existing problems and recommendations for future improvement. International journal of project management, 33(3), 623-637. 